\author{
HEZEKIAH OLUWOLE \\ ADEYEMI \\ ${ }^{1}$ Department of Mechanical Engineering, \\ Olabisi Onabanjo University, \\ Ago iwoye, Nigeria
} adeyemi.hezekiaht@oouagoiwoye.edu.ng

\section{EVALUATING PRODUCTIVITY TARGET AND ERGONOMICS SAFEGUARD: A HUMAN FACTOR STUDY OF BOTTLE MAKING INDUSTRY}

\begin{abstract}
This study evaluated the relationship between machinery operators' productivity efficiency (MOPE) and the machinery operators' on-the-job ergonomics satisfactions (MOOES) in Southwest Nigeria bottle making industry (BMI). The MOPE, for a period of one year, was computed for 50 semi-automatic PET blow machines operators in 12 bottle making industries. The subjective perceptions of the workers (category ratio scale - (CRS)) with respect to workloads elements and exposures to machine related hazards were measured using a questionnaire. MOPE results showed $78 \%$ of the studied subjects scored about $50 \%$ and their productivity were rated average. However, more than $92 \%$ of the operators suffered from mental, physical and environmental workload elements. With ttest, MOPE showed statistically significantly higher means value $(54.22 \pm 2.5, S E M=1.8)$ compared to MOOES $(34.40 \pm 2.75$, $S E M=.125), t(98)=23.309, p=.001$ hence, were significantly different $t$ - confirming a gap between machinery operators' ergonomics satisfactions and their productivity levels. The study suggested development of administrative measures capable of bridging the gap to enhance health and safety of the workers.
\end{abstract}

Key words: ergonomics, satisfaction, machinery, operators, productivity, bottle, industry.

\section{INTRODUCTION}

Productivity, defined as a ratio of output to input, is one of the most important factors that affect overall performance of any small, medium or large size industry. The input may comprise the resources used to produce output and the most common forms of input are labour and capital. Output could be in the form of goods produced and may be expressed in physical quantity (e.g. number of good items produced to reflect the physical effectiveness and efficiency of a process and/or labour, and are not affected by price fluctuations) or financial value (e.g. sales minus change in inventory level). Labour productivity, however, is the relationship between the quantity of labour output and the quantity of input used to generate the output. It is basically how effective and efficient the workforce in generating output with the resources available. Labour can be measured in three ways: number of hours worked, number of workers engaged and/or by the cost of labour. There are number of factors that directly affect productivity of labour, thus it is important for any organization to identify and measure those factors and take an appropriate action to improve their labour productivity [1].

Productivity measurement, however, plays an important role in the management of labour productivity. It helps to determine if the organization is progressing well and provides information on how effectively and efficiently human resources are managed. Hence, labour productivity measurement is a prerequisite for improving organization total productivity. Most commercial bottle making business (CBMC) in the South-west Nigeria are categorized under Small Scale Industry (SSI) going by the number of employee which is usually less than 50 [2] and plays some roles to development of the national economy. Growths of some CBMC have been constrained by different factors such as eratic power supply, lack of adequate funds among others leading to a very low capacity utilization and productivity. Gunu [3] stated that high productivity in Nigeria's SSI is a necessary condition at boosting GDP and uplifting the standards of living of the people just as Essien and Yakub [4] mentioned that raising the productivity of SSI is an effective vehicle for stimulating private-sector led growth. However, no high productivity target can be achieved without effective utilization of human resources. Subramaniam et al. [5] stated that humans play a major role on the industrial production shop floor, actively involved in the decision-making process, help greatly to meeting managements' targets, operate semi-automatic machines and many other functions. But many workers in this sector are affected by various 
types of work-related injuries. For instance, International Labour Organisation (ILO) [6] mentioned that risks are more prevalent among workers in SSI than in large scale enterprises. Ezenwa [7] reported 22 per 1000 workers been exposed to work related injuries per year in Nigeria Small and Medium Enterprise (SMEs) and that the exposures to injuries are more among young workers $[8,9]$. There is also a consensus that occupational health and safety is poorly managed among manufacturing industries in the developing countries [10]. High level of work related injuries were reported among the SMEs workers in Nigeria. Lack of training, low use of personal protective equipment, socio demographic, socio economic, personal work behaviour and poor working environment were reported by Sebsibe et al. [11) and Rongo et al. (12) among the leading causes. These contributed negatively to efficiency and productivity of many workers and those in the CMBC not excluded.

Though human being is highly adaptable but are not infinitely so. There are ranges of optimum conditions for any activity carried out by man. Ergonomics therefore helps to define what these ranges are and to explore the ergonomics hazards which occur if the limits are transgressed - for example if any of the physical (posture, manual lifting, repetitiveness), mental (job satisfactions, fatigue, job stress) and/or environmental (machinery noise, vibration, work speed) loads is too high or too low, labour productivity is affected $[13,14]$. Many industries have successfully implemented ergonomics solutions in their facilities as a way to address work related injury risks. Ergonomics is a multidisciplinary concept rooted in the design of jobs, tools, and work stations to fit the capabilities and limitations of workers. The main focus of ergonomics assessment of any workstation is to identify existing hazards or conditions where hazards may develop; hazard prevention and control to eliminate job hazards through workstation, work practice controls, use of personal protective equipment (PPE) and implementation of administrative control; training and education to enable employees to actively participate in the prevention. Relevance of ergonomics is however not fully understood in many industries in some developing countries. As reported by [15], most of the industries are characterised by improper workplace design, ill-structured jobs, mismatch between worker abilities and job demands, poor human-machine system design, inappropriate management programs and adverse environment. These lead to workplace hazards, poor workers' health, injuries and disabilities, and in turn reduce workers' productivity.

An effective intervention of ergonomics in work system design has been found to have positive effects on workers' performance, health, safety, satisfaction and can help to achieve a balance between workers' characteristics and task demands [16-19]. This present study evaluated the relationship between productivity target (of CMBC administrators) and the ergonomics functions in place to enhance machinery operators' safety and health at achieving the goal. The objectives were to evaluate the level of productivity, work load and the effects on operators' wellbeing and the subjective perceptions of workplace ergonomics.

\section{Significance of the study}

The study presents the subjective opinions of the weight allotted safety and health of machinery operators in comparison with the attention given to maximizing productivity. It provides assistance for the management to measure the opinions of a group of their workforce and the gap to bridge at meeting their desired ergonomic friendly workstations to ensure a safer working environment.

\section{.MATERIAL AND METHODS}

\section{The studied industry, machinery and task}

Fifteen (15) bottle making industries (BMI) engaging the use of semi-automatic bottle blow molding machine (SBBMM) located in Lagos, Oyo and Ogun states, the Southwest Nigeria, were included in the study. SBBMM was designed for fast producing polyethylene terephthalate (PET) plastic bottles. It is commonly used to produce the bottle water, carbonated drink bottle, pesticide bottle, oil bottle, cosmetics, to mention a few. The production of plastic bottles is in stages. Usually the plastic bottles are made from PET. The duties of the SBBMM operator were in stages. He manually fixed mold on blow machine. He positioned preform in an oven to heat the preform to the operator's predetermined temperature to form a parison. Two of the parisons were placed in a mold on a blow machine. The blow machine was prompted by the operator and the mold was closed. It was filled with highly pressurized air from a compressor, and stretch blow molding began: as a result of the pressurized air, heat and pressure, the parison was blown and stretched into the mold, assuming a bottle shape. The mold was quickly cooled either by the use of industrial chiller or by manual application of water on the mold so that the newly formed component was set properly. Once the bottle cooled and set, the mold was opened and the formed bottle is manually removed from the mold. The bottles were placed in a sack to be arranged by other workers ready for transportation.

Figure 1 shows an example of SBBMM, CM-12 Semiautomatic blow molding machine, especially used to produce different sizes of bottles [20].

\section{Subject selection}

All personnel working directly with the SBBMM (operators and managers), who were adequately experienced on the job and have spent at least 365 days, excluding holidays, on the machine were selected for the study. Some of the machinery were allocated to 2 operators (on different shifts) and were differently assessed during their shift period. 80 operators (male) and 50 managers (45 males and 5 females) were 
involved in the study. All potential volunteers agreed, and consents were taken in written form to have the interview conducted after they were informed that their participation in the study was voluntary. The purpose of the study and the confidentiality of the information provided were emphasized.

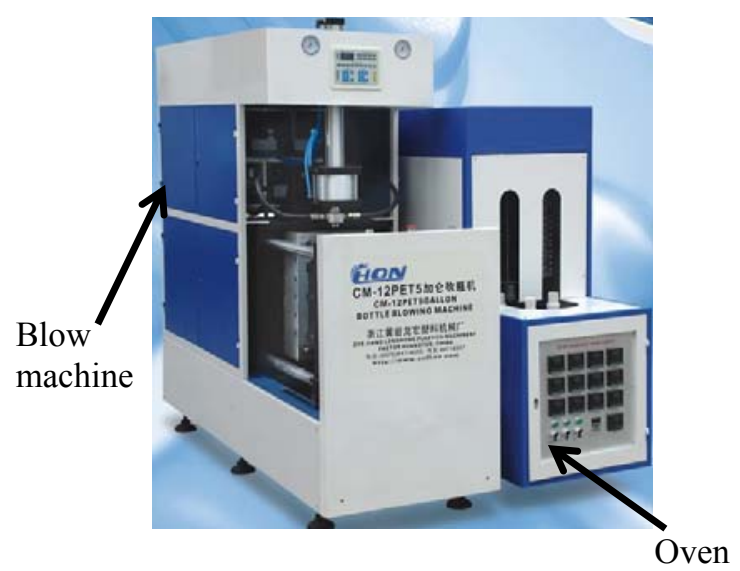

Figure 1. A typical CM-12 Semi-Automatic Blow Molding Machine

\section{Research tools}

Well-structured questionnaires, modified from machine checklists [21-25] were used as the research tools for collecting information on the operators' opinions, needs and expectations. The questionnaire contained personal background, work background, typical workday/shift plan, current work, work organization and psychosocial factors. Operators' physical load (such as body posture, repetitiveness), mental load (job stress) and environmental loads (machine speed, noise, vibration) were measured. The subjects were adequately tutored and asked to assign numbers to stimuli of different intensities in such a way that the numbers given match their perceptions. Category ratio scales (crs) from 0 to 10 were used as shown in Table 1. Ten (10) is defined as the strongest effort and exertion a person experienced on the job.

Table 1. Category ratio scale and interpretations

\begin{tabular}{|c|c|}
\hline Category ratio Scale & Interpretation \\
\hline 0 & Nothing at all \\
\hline 0.5 & Extremely weak \\
\hline 1 & Very weak \\
\hline 2 & Weak \\
\hline 3 & Moderate \\
\hline 5 & Strong \\
\hline 7 & Very strong \\
\hline 10 & Extremely strong \\
\hline
\end{tabular}

Source: Modified from Gunnar [22]

\section{Measurement of operators' productivity efficiency}

The operators' productivity efficiency was calculated from the study reported by Billikowki [26] and Pellikopf [27]. The ratio of actual input to the output that could be achieved if a plant ran at its maximum capacity for 365 days per year while producing $100 \%$ quality product (equations 1 to 3 ) were used. The actual outputs of each operator on each machine over a period of one year were obtained from the managers' record while the maximum capacity of each of the machinery was derived from the manufacturers' manual

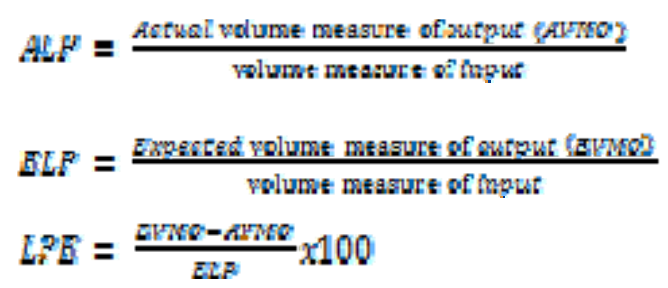

Where

ALP $=$ Actual Labour Productivity

ELP $=$ Expected Labour Productivity

$\mathrm{LPE}=$ Labour Productivity Efficiency

The output was the units of the average number of good bottles produced in the last 365 days and the input was the number of hours worked by the operators excluded hours paid but not worked (e.g. holidays, paid leave).

\section{Data analysis and statistical tests}

Statistical Package for the Social Sciences (SPSS) was used to analyze the collected data. The 50 calculated machinery operators' productivity efficiency (MOPE) results (in percentage) were compared with the machinery operators' on-the-job ergonomics satisfaction (MOOES) for correlation strength. Spearman's rho was used for significance tests of correlation coefficients at a p-value of 0.01 . Correlation strengths can be classified as weak, $0<|\mathrm{r}|<0.3$; moderate, $0.3<|\mathrm{r}|<0.7$; and strong, $|\mathrm{r}|>0.7$.

The independent sample t-test was used to analyse the means of the unrelated groups at $p<0.05$ for further confirmation. The independent sample t-test appraises whether the means for two independent groups are significantly different from each other.

\section{RESULT AND DISCUSSION}

\section{Workers response to interview}

One hundred and twenty-six $(96.9 \%)$ of the entire one hundred and thirty (130) workers (50 managers and 80 machinery operators) who participated in the study, completed the questionnaire. Table 2 shows the demographic of the subjects. The average age of machinery operators was 27 years while that of the managers was 47 years. Most of the machinery operators were 25 years of age and 3 years on their current job. Also, most of the administrators were 6 years on the business of making bottles from SBBMM. 
Table 2. The demographic and the statistic information of the subjects studied in 15 bottle making industry

\begin{tabular}{|l|l|l|l|}
\hline Description & $\begin{array}{l}\text { Job Experience } \\
\text { (years) }\end{array}$ & Age & $\begin{array}{l}\text { Operating } \\
\text { time (hours) }\end{array}$ \\
\hline Mean & $3.6(4.5)^{*}$ & $27(47)^{*}$ & 9.4 \\
\hline Mode & $3(6)^{*}$ & $25(50)^{*}$ & 8 \\
\hline $\begin{array}{l}\text { Standard } \\
\text { Deviation }\end{array}$ & $3.5(3.7)^{*}$ & $\begin{array}{l}3.1 \\
(4.6)^{*}\end{array}$ & 2.0 \\
\hline \multicolumn{3}{|c|}{()$^{*}=$ managers' data } \\
\hline
\end{tabular}

\section{Reported conditions of workplace, machinery and layouts}

From Figure 2, 96.8\% of the machine operators reported that oil spillages were not cleaned off immediately. This was because cleaning of the job floor was part of their assigned responsibility and the task was usually delayed till the end of day work. $85.8 \%$ stated that the machinery layout do not permit natural postures on duty. $83.4 \%$ and $78.2 \%$ of the workers reported that the emergency stops and warning labels respectively are not displayed on the machinery and in the work place. However about $87 \%$ mentioned that the exposures to dangerous machinery vibrations were minimized.

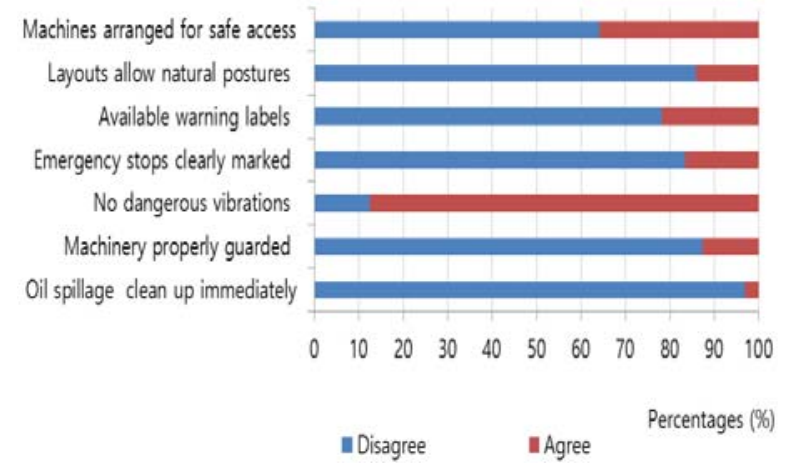

Figure 2. Operators' self-reported conditions of workplace, machinery and layouts

\section{Operators' reported available measures at improving ergonomics criteria on the job.}

As shown in Figure 3, 92.4\% reported that there was no provision for free medical care in their workplace. $87.5 \%$ mentioned that shift-work plan affected their normal scheduled rest period as $84.5 \%$ of this category craved for more recovery time outside work. Though the majority $(53.2 \%)$ mentioned that supervisors were assigned to them, they however reported that use of PPE were not enforced. $76.8 \%$ never attended any training in line with the machine handled or on safety measures.

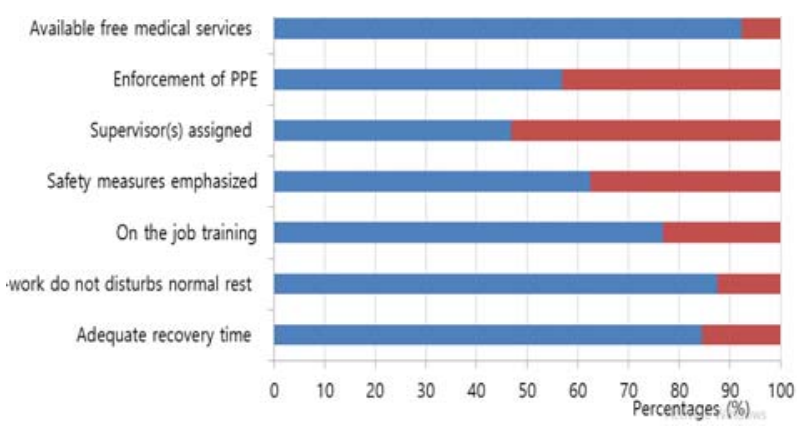

Figure 3. Operators' self-reported management decisions as it affected their works

Subjective perceptions of machinery operators' regarding workload elements

Figure 4 shows the measured results of some selected workload elements as they affected the workers. The interpretations of the ratings are as aforementioned in Table 1. More than $92 \%$ of the operators reported to have been afflicted by mental load. Of this percentage, an average CRS of 9.2 marks representing $92 \%$, was allocated by the machinery handlers to fatigue after daily work, 9.1 (91\%) allocated to job stress while 4.2 $(42 \%)$ was for job satisfaction. About ninety six percent $(95.6 \%)$ of the subjects complained affected by physical load element. In this category, an average rating of $7.82(78.2 \%)$ was assigned to awkward postures on the work, $6.5(65 \%)$ for manual material lifting, and 9.8 marks (98\%) for repetitiveness. An average of 9.2 (92\%) CRS was allotted to work speed by $94.8 \%$ of all the operators who complained of been affected by environmental load element. 8.4 (84\%) was allocated for job demands, 2.6 (26\%) was assigned to excessive machinery noise disturbance and 4.0 (40\%) for job control.

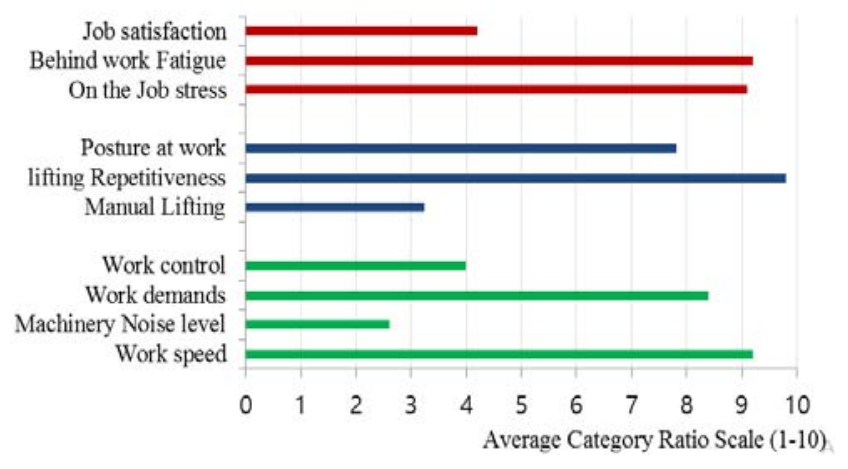

Figure 4. Operators' perceptions and responses to workload elements 


\section{Operators' reported on-the-job ergonomics} satisfactions

Figure 5 shows the average perceptions of the MOOES on how well they are comfortable carrying out their jobs on the machine. From the chart, majority of the subjects $(48 \%)$ scored their level of satisfactions between 31 to $49 \%$. $34 \%$ of the operators scored theirs below $30 \%$ mark, $14 \%$ of the participants rated their comfort level between 50 to $70 \%$. Only $4 \%$ of the subjects assigned above $70 \%$ marks.

\section{Above $70 \%$ score \\ 50 - $70 \%$ score \\ $31-49 \%$ score \\ Below $30 \%$ score \\ 0102030405060708090100 \\ Percentages (\%) of}

Figure 5. Workers' perceptions about on-the-job ergonomics satisfactions

\section{Operators' productivity}

Using the formula 1 to 3 above, the MOPE of 50 operators on their various machinery were calculated and the outputs showed (in Figure 5) that $42 \%$ had their productivity rated between $50 \%$ and $55 \%$, while $34 \%$ of the operators were ranked below $50 \%$. Only $2 \%$ was rated above $70 \%$ mark.

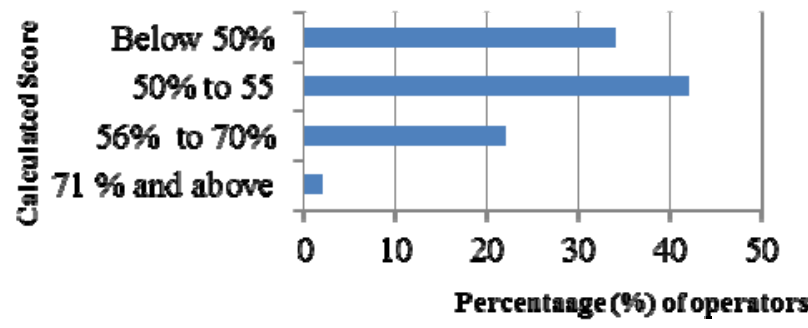

Figure 6. Result of the calculated operators' productivity efficiency

\section{Ergonomics enhancement versus operators' productivity levels}

\section{Comparing operators' self-rating on-the-job ergonomics satisfactions with their productivity level}

Figure 7 compared self-reporting MOOES with the MOPE results. $78 \%$ of all the subjects were rated above $50 \%$ (average performance) in terms of productivity, having scored at least 50\% mark. However, about 18\% of their subjects self-rated the ergonomics satisfactions enjoyed on the job above $50 \%$, indicating that $82 \%$ of the operators were not satisfied with the human factors considerations connected with the job.

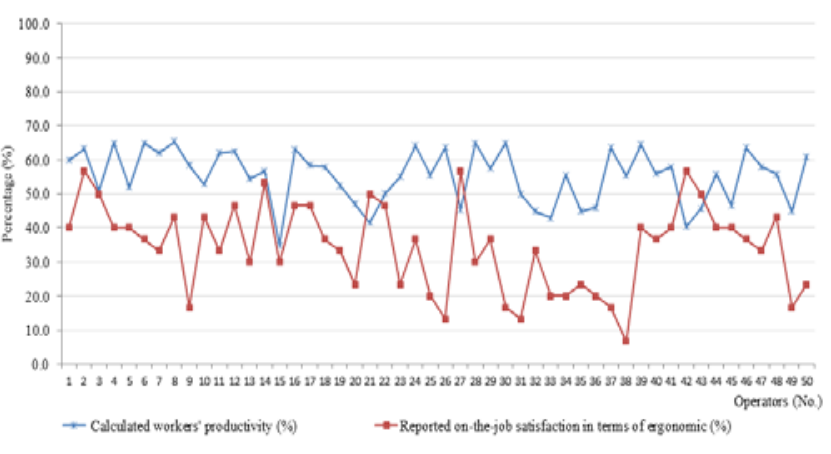

Figure 7. Comparison between percentage operators' productivity and the on-the-job ergonomics satisfaction levels of 50 operators on 50 SBBMM

\section{Spearman's Rank correlation coefficient statistics test between MOOES and MOPE}

After comparing the result of MOEES with that of MOPE for correlation strength using Spearman's rho, $\mathrm{r}=.019$ and $\mathrm{p}=.896$. It is obvious based on the result that the correlation is not significant. The coefficient of determination of 0.019 suggests $1.9 \%$ variability.

\section{Independent samples t-test between MOOES and MOPE}

For mean difference determination using independent sample t-test, MOPE showed a statistically significantly higher means value $(54.2 \pm 2.5$, SEM= $1.8)$ compared to MOOES $(34.40 \pm 2.75, \mathrm{SEM}=.125)$, $\mathrm{t}(98)=23.309, \mathrm{p}=.000$. However, since the value of "Sig. (2-tailed)" was lower than 0.05, the groups' means were significantly different.

\section{Discussions}

Labour productivity is one indicator commonly used to measure the overall productivity performance of employees in an organization. Efficient and effective utilization and, management of labour and, other factors to generate value added is a high significant level of the indicator. As noted in this study, performance levels of machinery operators were on the average. This was evidence from the $76 \%$ of the total operators' efficiency which were rated around $50 \%$. High pace of machine speed, the shift work plans and the efforts put in by the workers may have helped to achieve the average level of productivity performances. However, only $14 \%$ of the subjects apportioned at least an average mark of $50 \%$ and/or above to the satisfaction level derived on the job. The majority were unsatisfied with the efforts adopted by their employers regarding human factors criteria around the job.

According to Attar et al. [1], among many possible factors affecting labour productivity, workplace design, equipment, health/safety and working time factors are among the major. Most of the workers studied seemed to be affected by some of these factors if not all. Among the notable reported discomforts, fatigue after daily work, job stress, poor job satisfaction, awkward 
postures at work, manual material handling, repetitiveness, too fast work pace, and high job demands were mentioned. These may have greatly reduced their productivity performances to average levels. The majority of the workers opined that the shift-work plan characterized by the job affected their normal rest pattern and craved for more recovery time. The majority of the workers reported that their management do less at improving human factor elements required in their job compared to the demands for high productivity.

Statistically, the correlation between the operators' productivity efficiency and the satisfaction derived on the job is not significant. There exists a gap between the two groups meaning that the workers may be performing their duties under unsatisfactory conditions.

The workers' strove to satisfy their employers in terms of their productivity efficiency at the detriment of their comforts. This productivity result may not really be that the workers cared about or enjoyed the work they do but may partly be to gain the confidence of their employers on their suitability for the job and/or to at least keep the job so as to meet economic needs of their families. Such motives may not last for so long if there are perpetual injustices in the balance between their efforts and the satisfaction derived.

According to Osabiya, [28] unsatisfied employees produce less than their efficient potentials. Dissatisfied need of employees may jeopardize workplace peace and create increasing perception state of disequilibrium between efforts put in place by the employees and the benefits derived from the work. Therefore, if workers are to continuously contribute meaningfully to organizational growth and development, their individual needs should be considered so as to instil in them a sense of serious commitment and desire to contribute to the much desired progress of the system. Otherwise, if they are poorly managed workers have the potential to reduce the system growth pace. In addition to possibility of workers' poor service delivery aforementioned, job stress, fatigue after daily work and insufficient daily rest pattern characterized by operating semi-automatic PET blow machines can lead to an increased absenteeism. Awkward postures and repetitiveness reported by the workers can increase sufferings from musculoskeletal disorders. The manual material handling can also promote physical injuries as too high work pace has potentials to reduce job controls.

Modality to maintain a balance between organizational production targets and workers' comfort needs must be set out. The measure(s) will identify employees' desires and allow their free expression of emotions and feelings. This will enhance the comforts level, in terms of health and safety, of workers attached directly to the production assets and the feedback will be enhanced quality productivity and profits.

One of the limitations of this study is that the sample sizes were relatively small and the effects may underestimate the real-world opinions of the entire workers in the industry. Future efforts may however consider a wider coverage and other industries different from bottle production

\section{CONCLUSION}

The present study evaluated the relationship between productivity target set by managers and the ergonomics enhancement of machinery operators in Southwest Nigeria bottle making industry. The study showed average levels of operators' productivity efficiency. The performances were at average levels. Work fatigue, on-the job stress, high level of repetitive related discomforts and high level of job demands were the leading among all other complaints by the majority of the workers. In their opinions, workers desires for comfort on the work were not considered as part of the priority list of their managements. The poor human factor consideration of the job was however suspected as one major reason for the average productivity level.

The study identified gap between the managements' efforts at ensuring high productivity and the measures put in place to enhance job satisfactions level of the operators. The author, therefore, suggested development of measures capable of bridging the gap and enhance health and safety of the workers.

\section{REFERENCES}

[1] Attar, A. A., Gupta, A. K., and Desai, D. B. (2012). A study of various factors affecting labor productivity and methods to improve it. IOSR Journal of Mechanical and Civil Engineering - Second International Conference on emerging trends in engineering, SSN: 2278-1684. pp 1114.

[2] Hatten, T. S (2011). Small business management: entrepreneurship and beyond (5th ed.).Mason: SouthWestern Cengage Learning.

[3] Gunu, U. (2004). Small scale enterprises in Nigeria: their start up, characteristics, sources of finance and importance. Ilorin Journal of Business and Social Sciences, Vol. 9 Number 2, pp 6-43.

[4] Essien, A. E., Yakub A. B., (2007). Technical efficiency of small and medium scale industries in Nigeria: evidence from nation-wide sample survey. Studia Universitatis Babe Ş Bolyai, Negotia, Vol. 52(2), pp 39-69.

[5] Subramaniam, S. K. Hamidon, A. H. and Singh R. S. S. (2009). Optimization of available resources and methods of capitalizing human capital on industrial process lines efficiently. Wseas Transactions On Systems. Vol. 8 Number 6, pp 773-782.

[6] International Labour Organisation (ILO) Conference 91st session 2003. ILO standards-related activities in the area of occupational safety and health: An in-depth study for discussion with a view to the elaboration of a plan of action for such activities. ILO: IPEC action against child labour: Highlights 2002 (Geneva, 2002). www.ilo.org/public/english/standards/relm/ilc/ilc91/pdf/r ep-vi.pdf [7] Ezenwa, A. O. (2001). A study of fatal injuries in Nigerian factories. Occup. Med; Volume 51, pp 458-489.

[8] Bill, G. (2000). Census of fatal occupational injuries in Kansas: Kansas Department of Health and Environment; 
pp.1-15.

[9] Liv, X. R, Zhonghu, L., Dong, W., Sheng, Z., Bing, Z. Z. (2004). Relationship Occupational injuries with social and economic factors; Volume 22, pp 86-89.

[10] Diugwu, I.A. Baba, D.L. and Egila, A.E. (2012). Effective regulation and level of awareness: An expose of the Nigeria's construction industry. Open Journal of Safety Science and Technology. Volume 2 Number 4, pp 140-146.

[11] Sebsibe, T. Temesgen K. and Yalemzewod, A. (2016) Utilization of personal protective equipment and associated factors among textile factory workers at Hawassa Town, Southern Ethiopia. Journal of Occupational Medicine and Toxicology Volume 11 Number 6, pp 1-6

[12] Rongo, M. B., Barten, F., Msamanga 1, G.I., Heederik, D. and Dolmans, W. M. V. (2004). 'Occupational exposure and health problems in small-scale industry workers in Dar es Salaam, Tanzania: a situation analysis'/ Occupational Medicine, Volume 54, pp 42-46

[13] Anil P. S., Manisha, S. (2014). The factors affecting employee work environment \& it's relation with employee productivity international Journal of Science and Research (IJSR) Volume 3 Number 11, pp 27352729

[14] Health and Safety Executive (2013). Ergonomics and human factors at work. Available from http://www.hse.gov.uk/... Accessed November 12, 2016.

[15] Shikdar, A.A. and N.M. Sawaqed, (2003). Worker productivity and occupational health and safety issues in selected industries. Comput. Ind. Eng., Volume 45, pp 563-572

[16] Konz, S., 1995. Work design. Industrial Ergonomics, 2nd edn, Grid Columbus, Ohio.

[17] Grandjean, E., 1988. Fitting the task to the man: An ergonomic approach, Taylor and Francis, London.

[18] Wilson, J.R ., Corlett, E.N., 1992. Evaluation of human work: a practical ergonomics methodology. Taylor and Francis, Philadelphia.

[19] Occupational Safety and Health Administration (OSHA) (2008). Ergonomics for the prevention of musculoskeletal disorders. Publication 3341. Available from ttps://www.osha.gov

[20] Zhejiang H. L. (2017) CM-12 Semi-Automatic Blow Molding Machine. Available from http://www.cnlhon.com/products_view.asp?pId=7

[21] Industrial Accident Prevention Association (IAP) (2008). Machine safety. Available from www.iapa.ca Accessed April 15, 2015.
[22] Gorge Manson University (GMU) (2011). Machine and machine shop safety guide. Available from www.ehs.gmu.edu. Accessed November 18, 2014.

[23] Gunnar, B. (1990). Psychophysical scaling with applications in physical work and the perception of exertion. Scand. J. Work Environ Health. Volume16 Number 1, pp 55-5818.

[24] Hollmann, S, Klimmer, F, Schmidt, K-H, Kylian, H (1999). Validation of a questionnaire for assessing physical work load. Scand J Work Environ Health. Volume 25 Number 2, pp 105-114.

[25] Workplace Safety \& Prevention Services (2013) Machine safety http://www.wsps.ca/wsps/media/site/resources/downloa ds/wsps_machine-safety_2013_Accessed August 3, 2016.

[26] Billikopf, G. E. (2003) Labor management in a griculture : cultivating personnel productivity. 2nd Edition. ANR Publication 3417 The Regents of the University of California. https://nature.berkeley.edu/ucce50/aglabor/7labor/00.pdf

[27] Pelkowski, J. M. and M. C. Berger (2004), The impact of health on employment, wages, and hours worked over the life - cycle . Quarterly Review of Economics and Finance. Volume 44, pp $102-20$.

[28] Osabiya, B. J. (2015). The effect of employees' motivation on organizational performance. Journal of Public Administration and Policy Research Vol. 7(4) pp. 62-75

\section{BIOGRAPHY}

Hezekiah O. Adeyemi was born in Osun State, Nigeria. He recived the Ph.D. degree in Mechanical Engineering from the Federal University of Agriculture, Department of Mechanical Engineering, Faculty of Engineering, Abeokuta, Nigeria.

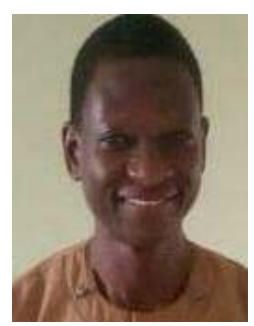
His main areas of research include human factor engineering, ergonomics, artificial intelligence and safety engineering. He is currently a lecturer at the department of Mechanical, Olabisi Onabanjo University, Ago-iwoye, Nigeria. 


\section{EVALUACIJA CILJEVA PRODUKTIVNOSTI I ERGONOMSKIH MERA: STUDIJA LJUDSKOG FAKTORA U INDUSTRIJI AMBALAŽE}

\section{Hezekiah Oluwole Adeyemi}

Rezime: U radu je prikazana evaluacija odnosa između efikasnosti produktivnosti operatera na mašinama $i$ njihove satisfakcije ergonomskim uslovima pri radu $u$ industriji ambalaže u jugozapadnoj Nigeriji. U toku jednogodišnjeg ispitivanja, izračunata je efikasnost produktivnosti u slučaju 50 operatera na poluatomatskim mašinama za PET ambalažu u 12 fabrika ambalaže. Subjektivna percepcija radnika (prikazana kroz skalu kategorije i skalu odnosa) u pogledu opterećenja i izloženosti opasnostima od mašina je izmerena pomoću upitnika. Rezultati procene efikasnosti produktivnosti operatera na mašinama pokazali su da je $78 \%$ ispitanika ocenilo svoju produktivnost kao prosečnu. Međutim, više od 92\% operatera je pretrpelo mentalno ili fizičko opterećenje, kao i opteré́enje zbog uticaja na životnu sredinu.. Rezultati t-testa ukazuju na statistički značajno veću vrednost efikasnosti produktivnosti $(54.22 \pm 2.5, S E M=1.8)$ u odnosu na satisfakciju ergonomskim uslovima $(34.40 \pm 2.75, S E M=.125), t(98)=23.309, p=.001$, čime se dolazi do zaključka da postoji jaz između satisfakcije ergonomskim uslovima i nivoa produktivnosti operatera na mašinama. U studiji je dat predlog razvoja administrativnih mera za poboljšanje zdravlja i bezbednosti radnika.

Ključne reči: ergonomija, satisfakcija, mašine, operateri, produktivnost, ambalaža, industrija 